\title{
Histological Effect of Aqueous Zingiber Officinale (Ginger) Root Extract On the Stomach of Adult Male Wistar Rats
}

\author{
*Eru, Eru M., *Uruakpa, Kelechi C., *Isamoh, Theresa E., "Inyang, Imeobong \\ J. *Otu, Mesembe E., \&*Anozeng O. Igiri, \\ *Department Of Human Anatomy, Faculty of Basic Medical Sciences, University Of Calabar, Calabar-Nigeria. \\ ${ }^{\#}$ Department of medical laboratory science, Faculty of Allied medical science University Of Calabar, Calabar- \\ Nigeria.
}

\begin{abstract}
Zingiber officinale commonly known as "Ginger' 'is a rhizome of the monocotyledonous perennial plant. Ginger is used as a remedy for treating many ailments such as arthritis, painful menstrual periods, nausea etc and contains sesquiterpenoids and monoterpenoids. The sesquiterpenoids include (-) zingiberene as the main component, lesser $\beta$-sesquiphellandrene, bisabolene and fernesene, while the monoterpenoids include $\beta$-phellandrene, cineol and citral. This study aimed to elucidate the effects of ginger on the histomorphology of the stomach using male adult wistar rats. Thirty adult wistar rats weighing between 190-200g were divided into control (group A) and two experimental groups $B$ and $C$, each group containing ten rats. The animals in control group A received water only while the experimental groups $B$ and C received $9 m g / k g$ of ginger for 14 and 28 days respectively. 24 hours after the last administration, the animals were sacrificed and routinely processed histologically. At the end of the experiment, the results showed no significant changes compared to the control group. The cells, lamina propria, gastric pit, submucosa, muscularis externa and the serosa remain the same as that of the control.
\end{abstract}

Keywords: Ginger, Stomach, Wistar Rats

Abbreviation: DNA= Deoxyribonucleic acid, $G_{0}=$ Quiescent Stage, $G_{I}=$ GaplPhase, GIT= Gastrointestinal tract, $\mathrm{HCl}=$ hydrochloric acid, $\mathrm{M}=$ Mitotic Phase

\section{Introduction}

For years, many medicinal plants are used for treating various ailments with unknown mechanisms. Herbs and spices used by humans to season food produce useful medicinal compounds (Tapsell et al 2006) to maintain human health and other animals. As the number of herbal medicines increases, herbalists trade billions of dollars annually, and Ginger is one of such medicinal plants.

Ginger is a rhizome of the monocotyledonous perennial plant though called "root" and is used for treating many ailments such as arthritis, colic diarrhoea, heat condition, common cold, flu-like symptoms, headache and painful menstrual periods (Altman et al, 2001), and also contain essential chemicals such as sesquiterpenoids and monoterpenoids, the sesquiterpenoids include (-) zingiberene as the main component, lesser $\beta$-sesquiphellandrene, bisabolene and fernesene, while the monoterpenoids include $\beta$-phellandrene, cineol and citral (Calvert I 2005).

According to Mowrey and co-workers in 1982, reported that ginger aids digestion, absorption, relieve constipation and flatulence in the GIT by increasing the activity of the smooth muscle and also reduce nausea and vomiting significantly, has no effect on the histology of the stomach of adult wistar rats when combined with honey (Eru et al 2013). Some studies also suggested that ginger has antitumor effects on colon cancer cells by suppressing its growth, striking the Go/G1 phases, reducing DNA synthesis and inducing apoptosis (Abdullah et al, 2010).

The stomach develops from the foregut and appears first as a fusiform dilatation or an enlargement around the middle of the fourth week (Moore et al 2008). It is the most distensible part of the GIT located in the upper left abdominal quadrant where ingested food are stored and digested. It is made up of four parts: the cardia, the fundus, the body and the pylorus (Moore et al 2006). Microscopically, the stomach is made up of four layers: the mucosa, submucosa, muscularis externa and the serosa (Victor 2006). The internal surface of the stomach is thrown into numerous folds called gastric rugae. Some cells in the gastric mucosa are responsible for the production of $\mathrm{HCl}$, pepsin, intrinsic factor and the hormone gastrin and some undifferentiated cells multiply to replace other cells (Victor 2006).

Hence, this study aimed to elucidate the histological effect of zingiber officinale on the stomach of adult wistar rats. 


\section{Materials And Methods}

Thirty adult wistar rats weighing 190-200g were diveded into three groups A, B and C of ten rats each. Group A served as the control had access to animal chow and water only. After feeding the experimental groups for an hour, Group B and C were administered $9 \mathrm{mg} / \mathrm{kg}$ of ginger for two and four weeks respectively. All animals were sacrificed 24 hours after the last administration, the stomach excised and fixed in Bouins fluid. Following complete fixation of the stomach, routine histological processing was carried out. The stomach sections were stained with haematoxylin and eosin stains and viewed under light microscope.

\section{Results}

The photomicrograph of the control group (plate 1) showed normal mucosa, submucosa, muscularis externa and serosa.

In the experimental groups (plate $2 \& 3$ ) treated with $9 \mathrm{mg} / \mathrm{kg}$ of ginger showed no significant changes. The experimental groups showed normal gastric mucosa, submucosa, muscularis externa and serosa.
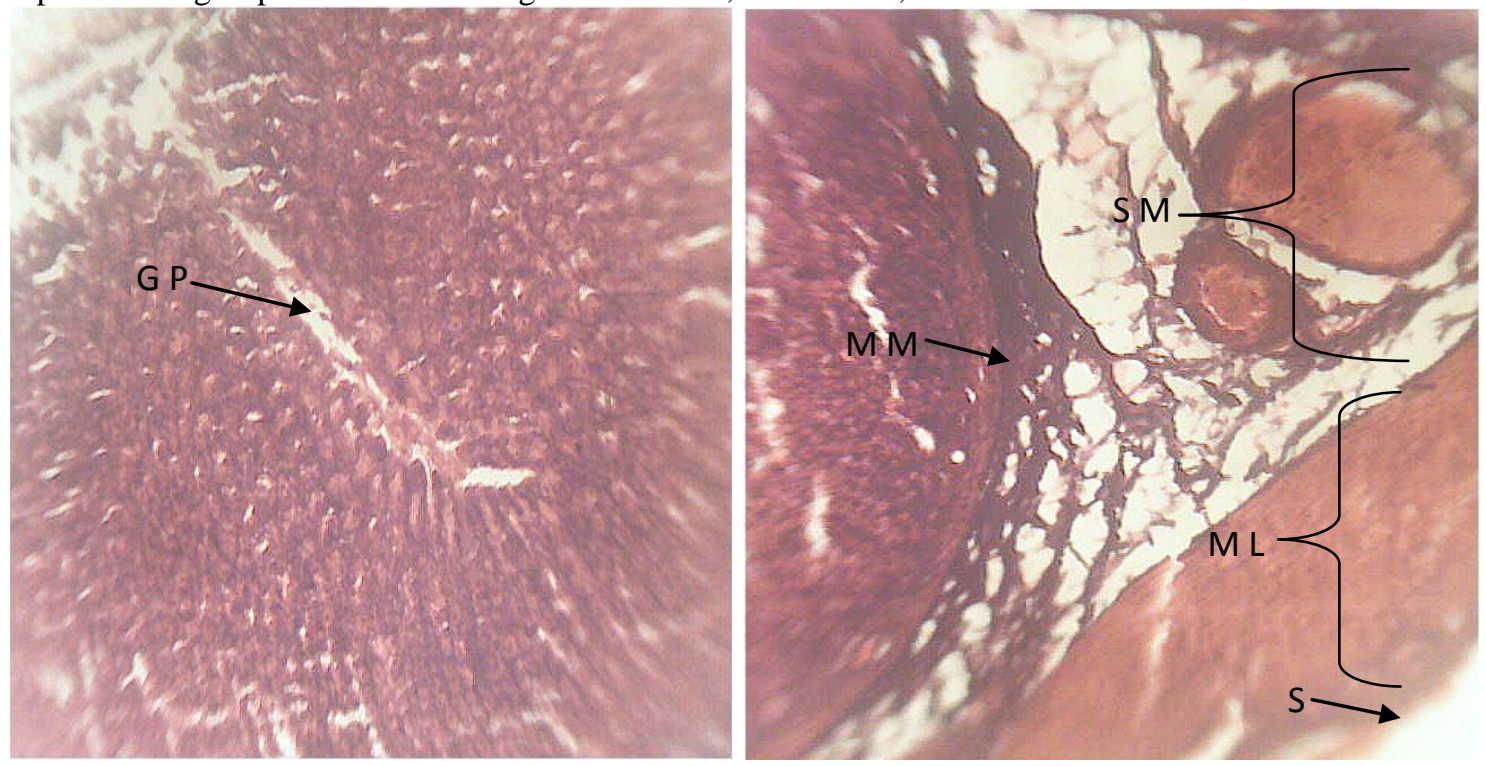

Plate 1: Group A (control)

Section of the stomach from rat given distilled water using H\&E stains, (X100) reveals normal gastric mucosa, submucosa, muscle layer and the serosa.
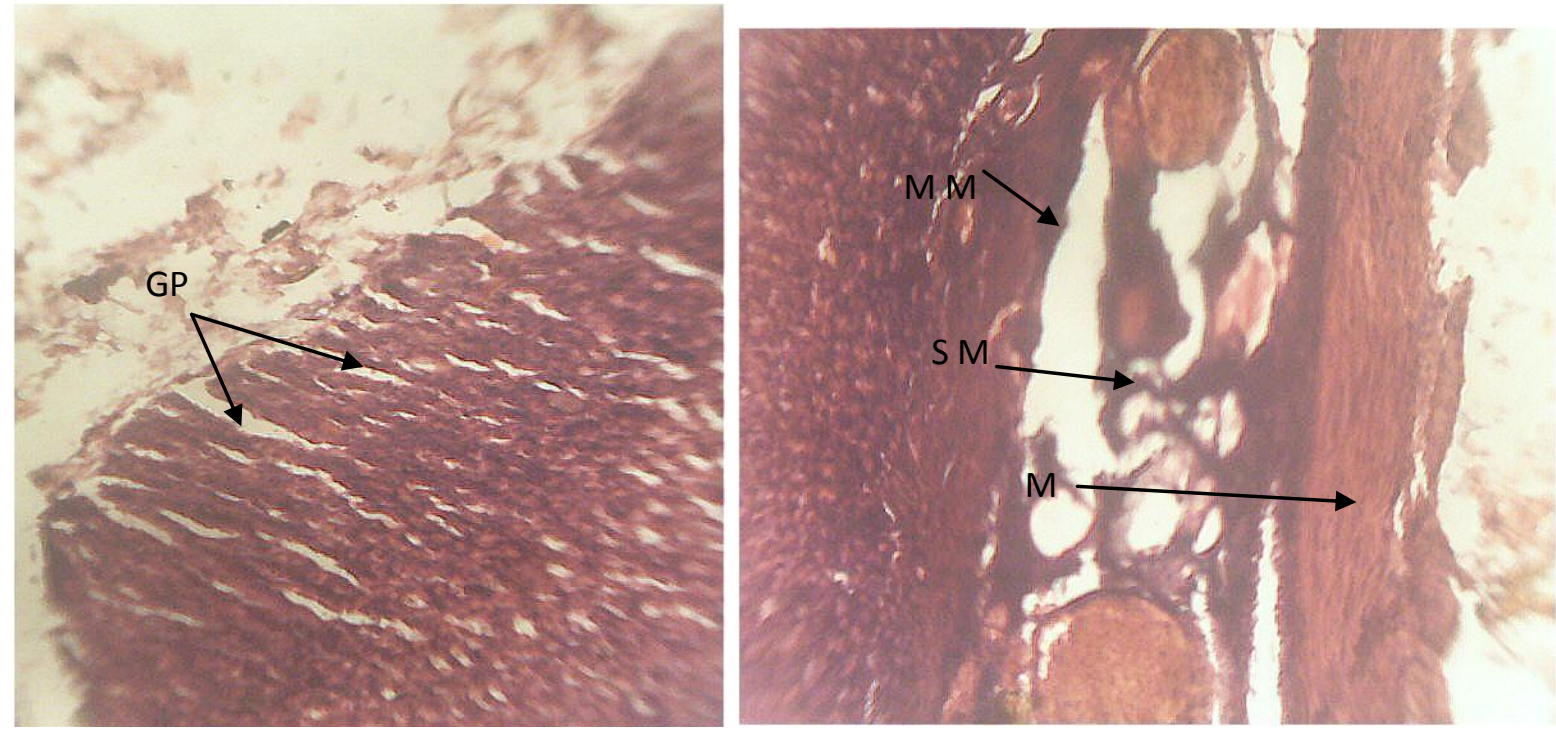

Plate 2: shows a photomicrograph (X100) of a sectioned stomach from the group of animals which received $9 \mathrm{mg} / \mathrm{kg}$ of ginger for 14 days. This showed normal histomorphology of the stomach. 


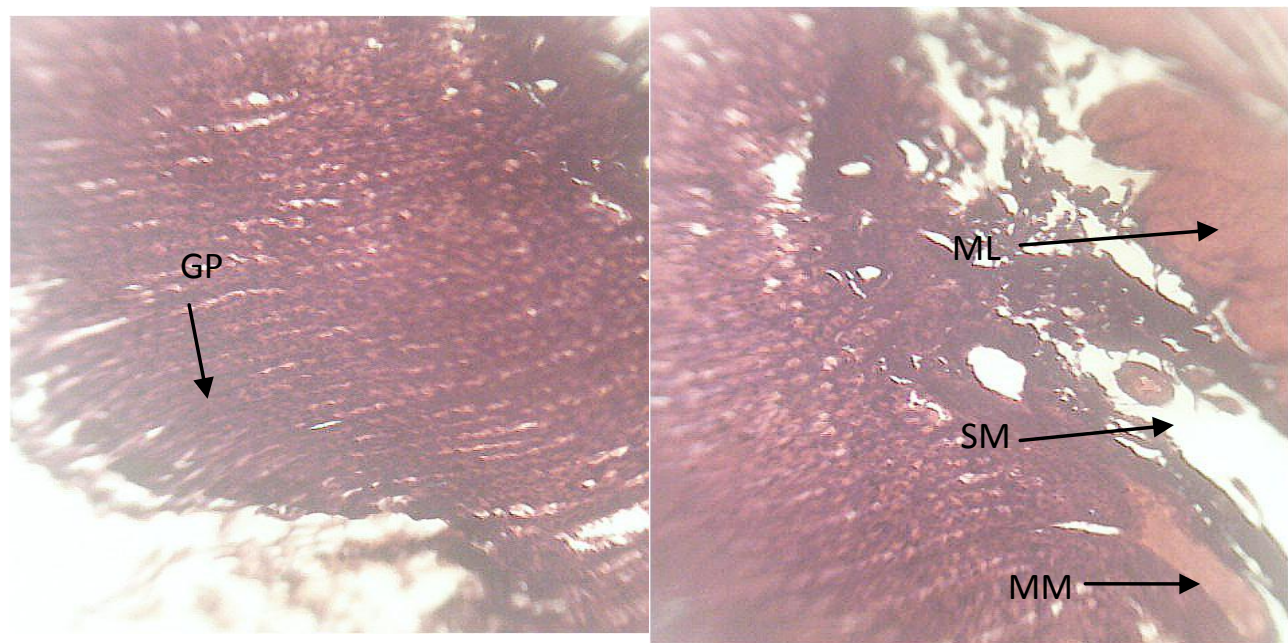

Plate 3: photomicrograph (X100) Of a sectioned stomach from the animals treated with $9 \mathrm{mg} / \mathrm{kg}$ of ginger for 28 days. This showed normal histomorphology of the stomach.

Keys: GP: gastric pit; ML: muscle layer; MM: muscularis mucosa; SM: submucosa; S: serosa

\section{Discussion}

Ginger is a rhizome though referred to as a root and had long been used for treating ailments like every other herbs in the world for centuries such as diarrhoea, common cold, heat condition, flu-like symptoms, headache and painful menstrual periods (Altman et al, 2001). Ginger contains sesquiterpenoids and monoterpenoids. The sesquiterpenoids is the main constituent and includes $\beta$-sesquiphellandrene, bisabolene and fernesene whereas the small fraction of monoterpenoids includes phellandrene, cineol and citral (Calvert I 2005). In 1982, Mowrey and co-workers reported that ginger aid digestion, absorption and relieves flatulence in GIT by increasing the muscular activity. In 2010, Abdullah and co-workers suggested that ginger has antitumor effect on colon cancer by suppressing its growth, striking the $\mathrm{G}_{0} / \mathrm{G}_{1}$ phases, reducing DNA synthesis during cell cycle and inducing apoptosis. According to Eru and co-workers in 2013 suggested that combined extract of ginger and honey showed no histological effect on the stomach which received $9 \mathrm{mg} / \mathrm{kg}$ of ginger and $228 \mathrm{mg} / \mathrm{kg}$ of honey to the experimental rats.

This study aimed to elucidate the effect of ginger on the histomorphology of the stomach using male adult wistar rats. Thirty male wistar rats weighing between 190-200g were used and divided into three groups, each group containing 10 rats in a cage. Group A was used as control, group B and C received $9 \mathrm{mg} / \mathrm{kg}$ of ginger for two and four weeks respectively. All animals were sacrificed 24 hours after the last administration; the tissues were processed using routine histological technique. After tissue processing, the control showed normal histological features. The experimental groups that took $9 \mathrm{mg} / \mathrm{kg}$ of ginger for two and four weeks showed no significant histological changes. This study suggests that there is no alteration to the histomorphology of the stomach after ingesting the extract made from ginger.

From the above report, it can be concluded that extract of ginger has no noticeable adverse effects on the integrity of the stomach histology but rather may be protective and aid digestion in line with Mowrey and co-workers (1982) by increasing the smooth muscle activity and cell proliferation and also, Eru et al (2013) suggested that combined extracts of honey and ginger has no noticeable effect on the histomorphology of the stomach. Further studies should be carried out using electron microscope on the cells of the stomach and also increasing the dose.

\section{References}

[1] Tapsell L. C, Hemphill I, Cobiac L, et al (2006). Health benefits of herbs and spices: the past, the present, the future. Med. J. Aust. 185 (4 suppl). 2006, 54-24. PMID17022238.

[2] Altman, R. D and Marcussen, K. C.. Effects of ginger extract on knee pain in patients with osteoarthritis. Arthritis Rheum, pubmed-indexed for medline 44 (11), 2001, 2531-2538.

[3] Calvert, I (2005). Ginger: an essential oil for shortening labour? Pract. Midwife 8 (1): 30-34

[4] Mowrey DB and Clayson DE, (1982). Motion sickness, ginger and psychophysics. Lancet i, 6557

[5] Abdullah, S., S. A. Z. Abidin, N. A. Murad, S. Makpol, W. Z. W. Ngah, Y. A. M. Yusof.Ginger extract (Zingiber officinale) triggers apoptosis and G0/G1 cells arrest in HCT 116 and HT 29 colon cancer cell lines. African Journal of Biochemistry Research, 4(4) 2010, 134142 .

[6] Keith L. Moore, T. V. N. Persaud. The Developing Humans: Clinically Oriented Embryology $8^{\text {th }}$ (ed). (1600 John F. Kennedy Boulevard suite 1800 Philadelphia, 2008) PA 19103-2899: 213-216.

[7] Keith L. Moore, Arthur F. Dalley. Clinically Oriented Anatomy. $5^{\text {th }}$ (ed). (Lippincott Williams \& Wilkins Philadelphia, 2006) PA 19106: 248-259.

[8] Victor P. Eroschenko. Difiore's Atlas of Histology: with functional correlations $10^{\text {th }}$ (ed). (Lippincott Williams \& Wilkins Baltimore, 2006) MD 21201; 238-251.

[9] Eru, M. Eru, Kebe, E. Obeten, Kelechi C. Uruakpa,\& Mesembe O. E. (2013). Histological evaluation of the combine extracts of aqueous zingiber officinale (ginger) root and honey on the stomach of adult wistar rats. Global Journal of Biology, Agriculture \& Health Sciences, 2 (4) 2013, 43-45. 